\title{
わが国における NAFLD/NASH の展望
}

\author{
金守良, $*, a$ 金 啓二b
}

\section{An Overview of NAFLD/NASH in Japan}

\author{
Soo Ryang Kim*,a and Ke $\mathrm{Ih} \mathrm{Kim}^{b}$ \\ ${ }^{a}$ Department of Gastroenterology, Kobe Asahi Hospital; 3-5-25 Bououji-cho, Nagata-ku, Kobe 653-0801, Japan: and \\ ${ }^{b}$ Department of Pharmacy, Kobe Asahi Hospital; 3-5-25 Bououji-cho, Nagata-ku, Kobe 653-0801, Japan.
}

(Received September 22, 2015)

\begin{abstract}
Clinical identity of nonalcoholic steatohepatitis (NASH) has established it as a chronic liver disease since the 1990s in the USA and in the 21st century in Japan, although its significance is not well recognized in Japanese society. It is characterized as a chronic liver disease, differentiated from viral liver disease and alcoholic liver disease. Nonalcoholic fatty liver disease (NAFLD) comprises nonalcoholic fatty liver (NAFL) and NASH. NASH is considered to be the hepatic manifestation of a metabolic syndrome. It is understood that among individuals with NAFLD, NAFL is a benign condition, whereas NASH can progress to cirrhosis and ultimately to hepatocellular carcinoma. The precise mechanism of NASH is poorly understood, although insulin resistance, oxidative stress and multiple parallel hits theory have been reported. Computed tomography and ultrasonography are performed to detect NAFLD, but these are not sufficient to distinguish between NAFL and NASH. The distinct diagnosis of NAFL and NASH is currently made by liver biopsy, requiring hospitalization. Therefore, there is an urgent need to develop simple, non-invasive markers that can accurately distinguish between NASH and NAFL. In Japan, the number of NASH patients is estimated to be about 1 million. The treatment of NASH comprises changes in life style, including eating habits and exercise that will lead to weight loss, and drug intake, including vitamin E. Based on the global increase in obese people, NASH as a chronic liver disease will become the most important chronic liver disease in the 21st century, not only in Japan but also worldwide.
\end{abstract}

Key words_ nonalcoholic steatohepatitis; nonalcoholic fatty liver disease; life style

\section{1.はじめに}

慢性肝臓病としての非アルコール性脂肪性肝炎 (nonalcoholic steatohepatitis; NASH) は，20 年前 から米国で, 日本でも 10 年前から疾患概念として 確立されたが，その重要性は，まだ社会全般に認識 されていない. 2006 年, メタボリックシンドロー ムという医学用語が流行語大賞になり，その言葉は すっかり社会に定着したのとは対照的である.た だ，非アルコール性脂肪肝 (nonalcoholic fatty liver disease；NAFLD）は世界中で 21 世紀において，最 も一般的な肝疾患になりつつある。NAFLD は単純 脂肪肝 (nonalcoholic fatty liver; NAFL) と NASH

$a$ 神戸朝日病院消化器科（干653-0801 神戸市長田区房 王寺町 3-5-25), $b$ 神戸朝日病院薬剂科（† 653-0801 神戸市長田区房王寺町 3-5-25)

*e-mail: asahi-hp@arion.ocn.ne.jp

本総説は, 日本薬学会第 135 年会シンポジウムS32 で 発表した内容を中心に記述したものである.
から成り立つ。NASH は，一言でいえば，メタボ リックシンドロームの肝蔵病ともいうべき疾患であ る. NAFLD のうち, NAFL は良性病変であるが, NASH は肝線維化, 肝硬変, ひいては肝がんにす すんでいく疾患である。後に述べるが，NASH の 治療法には決定打がないのが現状である。ただ，上 記に述べた理由から NAFLとNASH の鑑別は極め て重要である。今回, 日本消化器病学会から発行さ れた『NAFLD/NASH 診療ガイドライン 2014』 (以下診療ガイドライン) 1 )を中心に，NASH を含む NAFLD の定義, 有病率, 病因, 診断, 治療, 予後 について述べる.

\section{2. 定義}

診療ガイドラインでは，NAFLD は「組織診断あ るいは画像診断で脂肪肝を認め, アルコール性肝障 害など他の肝疾患を除外した病態」と定義した。ア ルコール性肝障害を鑑別する上での飲酒量の境界線 は，エ夕ノール換算で男性 $30 \mathrm{~g} /$ 日，女性 $20 \mathrm{~g} /$ 日以 
上の飲酒でアルコール性肝障害は発症し得ることか ら，それ未満の飲酒量である場合を NAFLD に含 めるとした。ただし，飲酒量に関してはエタノール 換算で男性 $20 \mathrm{~g} /$ 日，女性 $10 \mathrm{~g} /$ 日未満とする報告も あることを注釈として付け加えた。 また，NAFLD のうち病態がほとんど進行しない病態を，非アル コール性脂肪肝（NAFL）とした。これまでは肝細 胞障害を伴わない NAFLD は単純性脂肪肝（simple fatty liver）と称されることが多く，NAFLの名称 は日本人になじ夕難いのではないかとの指摘もあり 議論になったが，米国肝臓病学会（American Association for the Study of Liver Diseases; AASLD), 米国消化器病学会 (The American College of Gastroenterology; ACG/American Gastroenterological Association; AGA ) の practice guideline で は NAFL と記載されたことから，今後国際的に使用 されるようになる病名を採用した。NAFLD/ NASH と関連する病態としては, メタボリックシ ンドローム関連疾患のほかに内分泌疾患，高度の栄 養障害, 薬物性肝障害などがあるが，実臨床ではメ タボリックシンドロームに関連した NAFLD/ NASH の比率が高い. NASH は命名の過程からし て病理学的所見に基づいており, 今回のガイドライ ンでもそれに準じた定義が採用されたが，病因・病 態を反映した定義として，メタボリックシンドロー ム関連の metabolic fatty liver disease/metabolic steatohepatitis への名称変更が提案されていること も付記されている. ${ }^{2)}$

\section{3. 有病率}

飽食の時代を背景に肥満人口が世界の多くで増加 している，肥満は糖尿病，アルコール摂取などとと もに脂肪肝の原因となっている，現在，日本におい て腹部超音波検査を用いた検診によれば， 20 歳以 上の成人男子の脂肪肝の割合は $20 \%$ を超えてい る. 診療ガイドラインによると NAFLD と NASH に有病率については Table 1 に示す通りである.

NAFLD の有病率は，欧米諸国では 20-40\%，アジ ア諸国では 12-30\%，日本では9-30\%である.

NASH の有病率は世界的には 3-5\%で日本では 100 万人くらいと推定されている. 日本人の年齢分布で は，NAFLD，NASH ともに男性は中年層，女性で は高齢層である。が，NASH 肝硬変の有病率や年 齢分布についての正確な報告はない.
Table 1. Prevalence and Age Distribution of NAFLD in Japan and Worldwide

\begin{tabular}{|c|c|c|c|c|}
\hline & \multicolumn{2}{|c|}{ NAFLD } & \multicolumn{2}{|c|}{ NASH } \\
\hline \multirow{3}{*}{ Prevalence } & $\begin{array}{l}\text { USA and Euro- } \\
\text { pean countries }\end{array}$ & $20-40 \%$ & \multirow{3}{*}{\multicolumn{2}{|c|}{$\begin{array}{l}\text { Worldwide } 3-5 \% \\
\text { ※Around } 1 \text { million } \\
\text { people are estimated } \\
\text { in Japan. }\end{array}$}} \\
\hline & Asian coutries & $12-30 \%$ & & \\
\hline & Japan & $9-30 \%$ & & \\
\hline \multirow{2}{*}{$\begin{array}{l}\text { Age } \\
\text { distribution }\end{array}$} & Japanese Men & $\begin{array}{l}\text { middle- } \\
\text { age }\end{array}$ & $\begin{array}{l}\text { Japanese } \\
\text { Men }\end{array}$ & $\begin{array}{l}\text { middle- } \\
\text { age }\end{array}$ \\
\hline & $\begin{array}{l}\text { Japanese } \\
\text { Women }\end{array}$ & $\begin{array}{l}\text { advanced- } \\
\text { age }\end{array}$ & $\begin{array}{l}\text { Japanese } \\
\text { Women }\end{array}$ & $\begin{array}{l}\text { advanced- } \\
\text { age }\end{array}$ \\
\hline
\end{tabular}

※There is no accurate report regarding prevalence and age distribution of NASH related cirrhosis.

\section{4. 病因}

脂肪肝の原因として，肥満，糖尿病，アルコール 摂取があると既に述べたが，NAFLDすなわち，非 アルコール性脂肪性疾患からアルコール摂取者が除 外されることは言うまでもない。NASH の形成機 序については，古くから Two hits theory3) が提唱 されてきた。インスリン抵抗性を背景として，肝細 胞への脂肪沈着 (First hit) がまず起こり，その後, 肝細胞障害要因や遺伝的素因（Second hit）などが 加わることにより NASH が形成されるという仮説 である（Fig. 1)。 First hit である脂肪肝の形成は， 肥満や食事摂取過多による細胞への脂質輸送の増 加, 肝内 de novo 脂肪酸の増加, 肝細胞からの脂 質輸送障害などによって起こる。この時点では炎症 は起こっておらず，NAFL が形成されるのみであ る。しかしながら，ここに Second hitとして肝臓 に酸化ストレス，アポトーシス，エンドトキシン， アディポサイトカインなど複数の負荷が加わること により，NASH が発症するとされている．アディ ポサイトカインとは, 脂肪組織由来の生理活性物質 のことである。代表的なアディポサイトカインとし ては TNF- $\alpha$ ，アディポネクチン，レプチン，遊離 脂肪酸などが挙げられるが，これらのアディポサイ トカインの分泌バランスの異常により，インスリン 抵抗性や肝臓の炎症，線維化が誘導されると言われ ている。 また，最近では， Multiple parallel hits 仮 説が提唱されており（Fig. 1)，脂肪変性や炎症の 進展が連続的に起きるのではなく，並行して生じて くるという可能性も十分ある。一方, NAFLD の遺 伝的素因として，アディポニュートリンの遺伝子多 型 (patatin-like phospholipase domain containing 3 


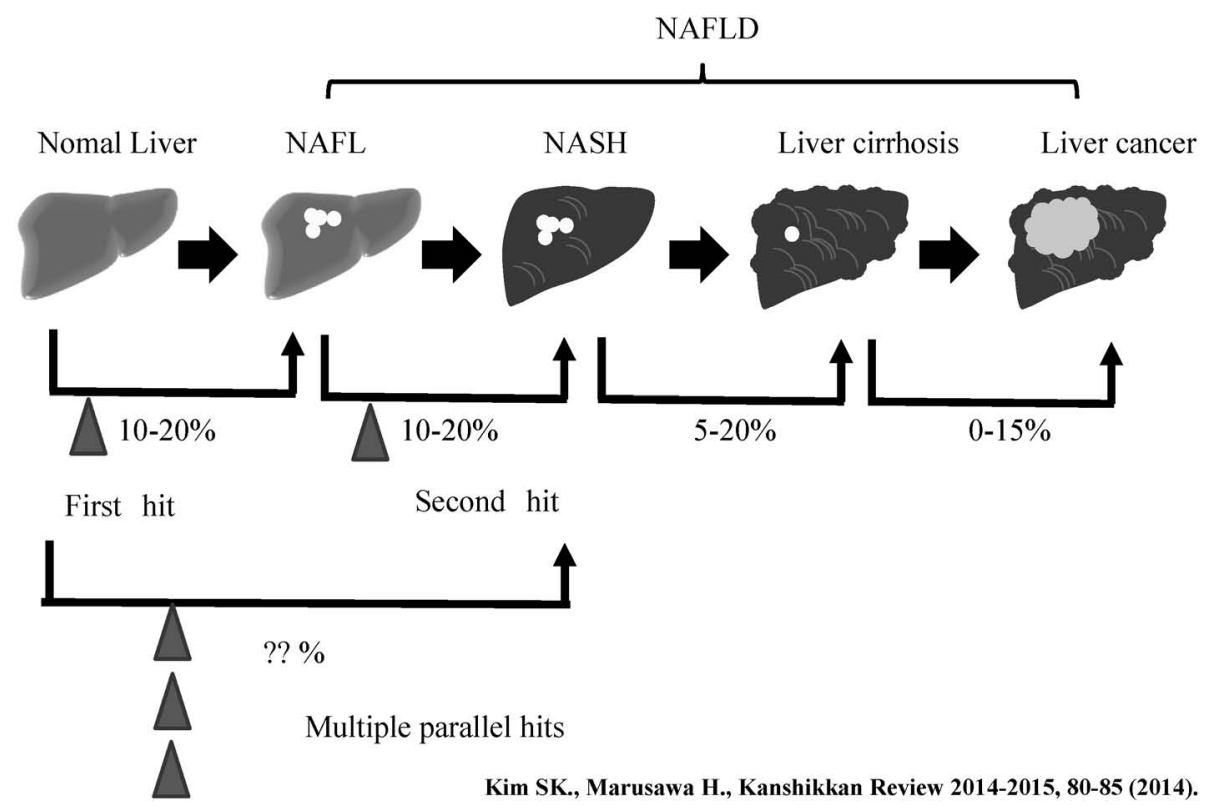

Fig. 1. Clinical Course from Normal Liver to NASH

gene；PNPLA3）が同定されている．近年，一度に 大量の遺伝子解析を行うことができる次世代シーケ ンサーの登場により，ゲノム全体をほぼカバーする ような 50 万個以上の一塩基多型 (single nucleotide polymorphism; SNP）の遺伝子型を決定することが でき，また，おもに SNP の頻度（対立遺伝子や遺 伝子型）と疾患との関連を統計的に調べるゲノムワ イド相関解析 (Genome Wide Association Study; GWAS）という方法論が普及し，各分野の疾患に ついて網羅的な検討が行われている。NAFL/ NASH の領域でも様々な報告がなされており，と くに 22 番染色体近傍に存在する PNPLA3 が, NAFLD の発症や線維化進展に関与している SNP であることが明らかになった。 ${ }^{4)}$ 日本人 NAFLD 患 者 529 症例（対照 932 例）を対象とした検討でも, PNPLA3 の SNP は Matteoni 分類 Type 4（線維化 を伴う NASH）と有意に相関していた。 ${ }^{5)} P N P L A 3$ は脂質代謝に関与するとされ，in vitro での解析 や，マウスを用いた in vivo での検討も行われてい るが，現時点で詳細な機能については明らかになつ ていない。ほかにも，GWASによって NAFLD/ NASH に関係する候補遺伝子の存在が報告されて いるが，このような方法論やPNPLA3 のような SNP の同定は，「NAFLD 患者のなかで誰が NASH になり，誰が線維化をきたすのか」というテーマを 解決する大きな手がかりになる可能性がある. $\left.{ }^{6}\right)$

\section{5. 診断}

診療ガイドラインの診断フローチャート (Figs. 2 and 3）では, 診断プロセスの導入部分として肝機 能障害と脂肪肝診断の 2 つの入口を設けた。 次のス テップとして，HBs 抗原， HCV 抗体などの肝炎ウ イルスマーカーや自己抗体を中心とする抗核抗体 (ANA）や抗ミトコンドリア抗体（AMA）などの 血清学的所見及び飲酒歴の聴取によって他の肝障害 を来たす疾患を鑑別し，NAFLDの診断に至る．問 診内容として飲酒歴はもちろんのこと, 外科手術 歴, 薬物服用歴, メタボリックシンドロームの有 無, 睡眠時無呼吸症候群の有無やホルモン分泌関連 疾患の除外など, NAFLD の原因及び併存疾患の有 無を確認することが必要になる. ${ }^{11}$

NAFLD の診断のうち脂肪肝については，超音波 検査 (ultrasound; US) やコンピュータ断層撮影 (computed tomography; CT) などの画像診断で可 能である.US については肝臓と腎臓のコントラス ト（いわゆる肝腎コントラスト）や肝エコーレベル の上昇（Bright liver）などの所見であり，CT につ いては肝（L） CT 值と脾（S） CT 值の比 $(\mathrm{L} / \mathrm{S})$ の低下，一般には 0.9 以下が診断に有用である。非 侵襲的な NASH の診断方法としてサイトケラチン (CK) 18 フラグメントなどのバイオマーカー, ${ }^{7,8)}$ Transient elastography の技術を用いた肝硬度測定 による線維化評価，各種スコアリングなどが知られ 


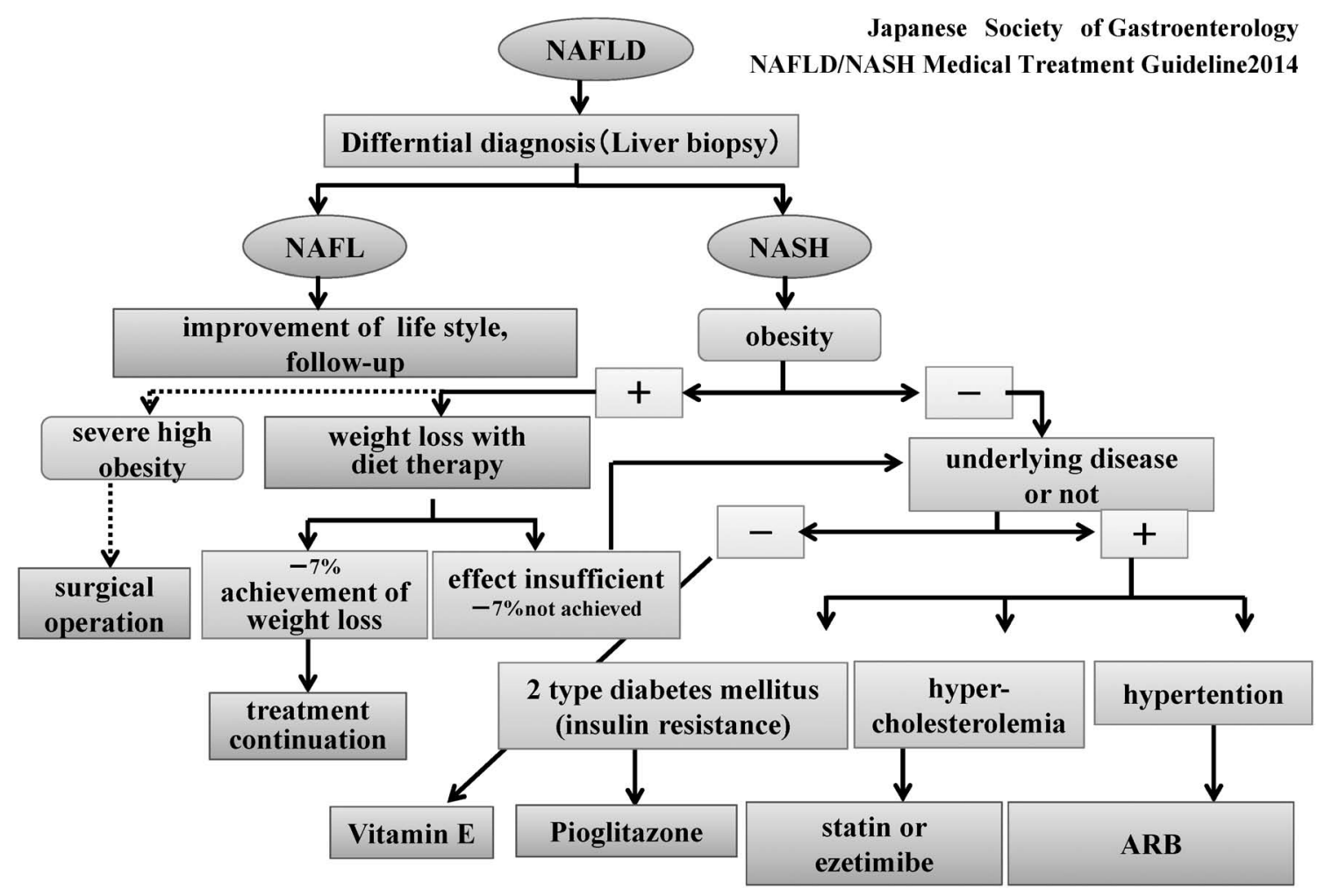

Fig. 2. NAFLD/NASH Diagnosis Flow Chart

ているが，現段階でいずれも決定的な診断ツールと なるまでには至っていない。 ただ，NASH の診断 については, 肝生検が今なお唯一の診断であり重要 である.

NASH の肝生検所見としては Figs. 4 and 5 で示 す通りである.

\section{6. 治療}

NAFLD/NASH の治療方針はNAFLと NASH で異なる．NAFLD/NASH の長期予後に対する有 効性が確立された薬物療法がなく, 肝病態が進行し ない NAFL では長期投与を行う根拠に乏しいため である.よって NAFL と診断された場合は，食生 活の是正と運動療法を軸とした生活習慣の改善を行 いつつ経過を観察する，一方，進行性の病態である NASH に対しては薬物療法も含めた検討による と，肥満がある症例では安全性や費用対効果の面か らまず食事運動療法を行い体重減少による病態改善 を目指す（Fig. 2)。低カロリー食による体重の減 少は, NAFLD 患者の肝機能, 肝脂肪化を改善させ る. NAFLD，NASH の改善にはエネルギー摂取量 の適正化を優先し，栄養素摂取比率では脂質を制限 する. NASH に対する生活習慣の介入試験にて 7\%
以上の体重減少で肝細胞の脂肪沈着，肝小葉の炎 症, 肝細胞の膨化の減少が得られたとの報告があ る. ${ }^{9)}$ 診療ガイドラインでは, 7\%の体重減少の有無 を食事運動療法の成否のボーダーラインと設定し, $7 \%$ 以上の体重減少が得られれば肝機能を再評価の 上で治療を継続し，体重減少が得られなければ薬物 療法に移行することとした。また，運動は有酸素運 動が適しており，30 分間を目安とし，できるだけ 毎日するのが好ましい。もつとも，非肥満者であっ ても運動療法による肝脂肪の改善効果が得られたと の報告が近年散見されており，非肥満者であっても 運動療法を併用しながら治療介入していくことが望 ましい. 2)

薬物治療については，決定打はない。とりわけ線 維化の改善に有効であるエビデンスのあった薬物は 極めて少ない。診療ガイドラインでは, ビタミン $\mathrm{E}$ (Vitamin E) とチアゾリジン誘導体（Thiazolidinediones）以外にエビデンスレベルの高い肝 組織改善薬はない. World Health Oraganization (WHO) Global Guidelines では，上記の薬物におい ても十分な検証がされておらず， experimental（実 験的）な薬物として考えるべきだとしている. ${ }^{1)}$ 


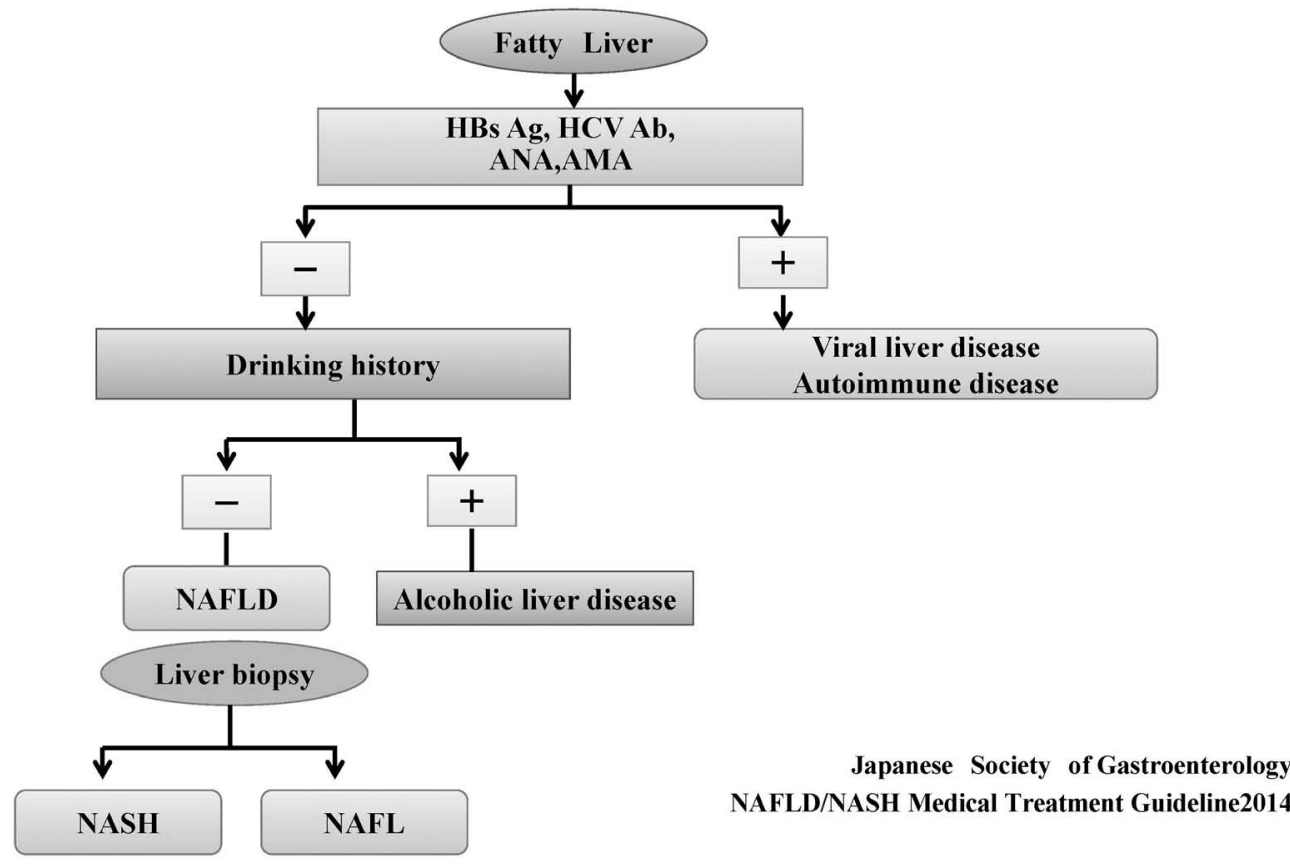

Fig. 3. NAFLD/NASH Diagnosis Flow Chart

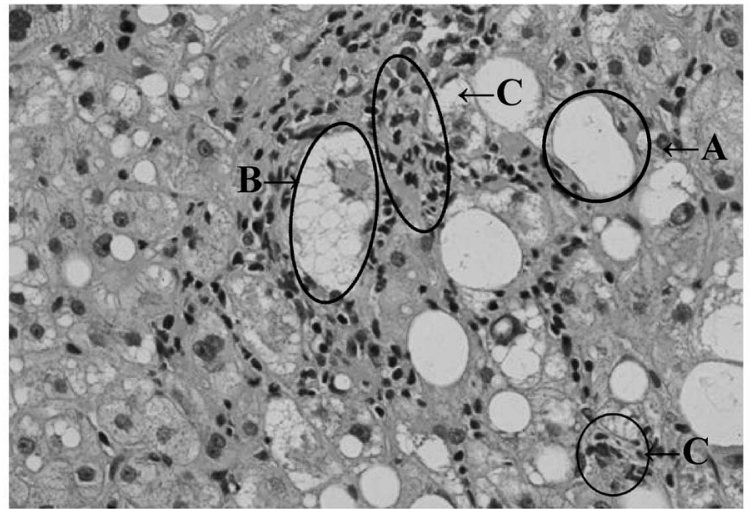

- $\mathrm{A} \rightarrow$ White circle shows fat accumulation

- $\mathrm{B} \rightarrow$ Ballooning is observed

- $\mathrm{C} \rightarrow$ Dark blue cells show inflammatory cells

Fig. 4. Histopathological Findings of NASH

以下，薬物療法について述べる.

1) ビタミン $\mathrm{E}$

基礎疾患が特にない場合，ビタミン $\mathrm{E}$ による治 療を考慮する.NASH の発症機序として酸化スト レスの増加が指摘されており，抗酸化作用を有する ビタミン E が NASH 治療薬の候補になつた。 2000 年ごろからビタミン E が NASH の病態に対して肝 関連の検查值及び肝病理所見を改善させたとの報告 がされるようになり，2010 年に米国で成人の
$\mathrm{NASH}$ 症例 247 例に対してビタミン $\mathrm{E}$, プラセ ボ，ピオグリタゾン投与群に分けた 96 週間の大規 模 randomized controlled trial（RCT，ランダム化比 較試験）いわゆる PIVENS 試験が行われた。この 試験でビタミン $\mathrm{E}$ 投与群は血清 ALT 值及び肝脂肪 化，炎症の有意な改善が認められ，NASH 病態の 有意な改善を示した. ${ }^{10)}$ 特にビタミン E はピオグリ タゾンと比して炎症，脂肪化などの肝組織所見にお いて有効であったというインパクトのある結果で あった。ただし，肝線維化に対してはピオグリタゾ ン同様に改善効果が認められず，長期投与の有効性 を示すには至らなかった。また，小児 NAFLDを 対象とした他の臨床試験ではプラセボ群と比較して 有意な改善効果が得られなかったと報告されてお り, 安全性の確認も含め今後の検証が必要であ る. ${ }^{2)}$

2) ピオグリタゾン

ピオグリタゾンはチアゾリジン誘導体の 1 つでペ ルオキシソーム増殖因子活性化受容体（peroxisome proliferator-activated receptor; PPAR) $\gamma$ のアゴニ ストとして働き，インスリン抵抗性改善薬として糖 尿病治療に用いられている。 NASH の病態形成に インスリン抵抗性が深く関与していることから，ピ オグリタゾンは NASH 治療薬の候補として注目さ れてきた。ピオグリタゾンは基礎的実験でアディポ 


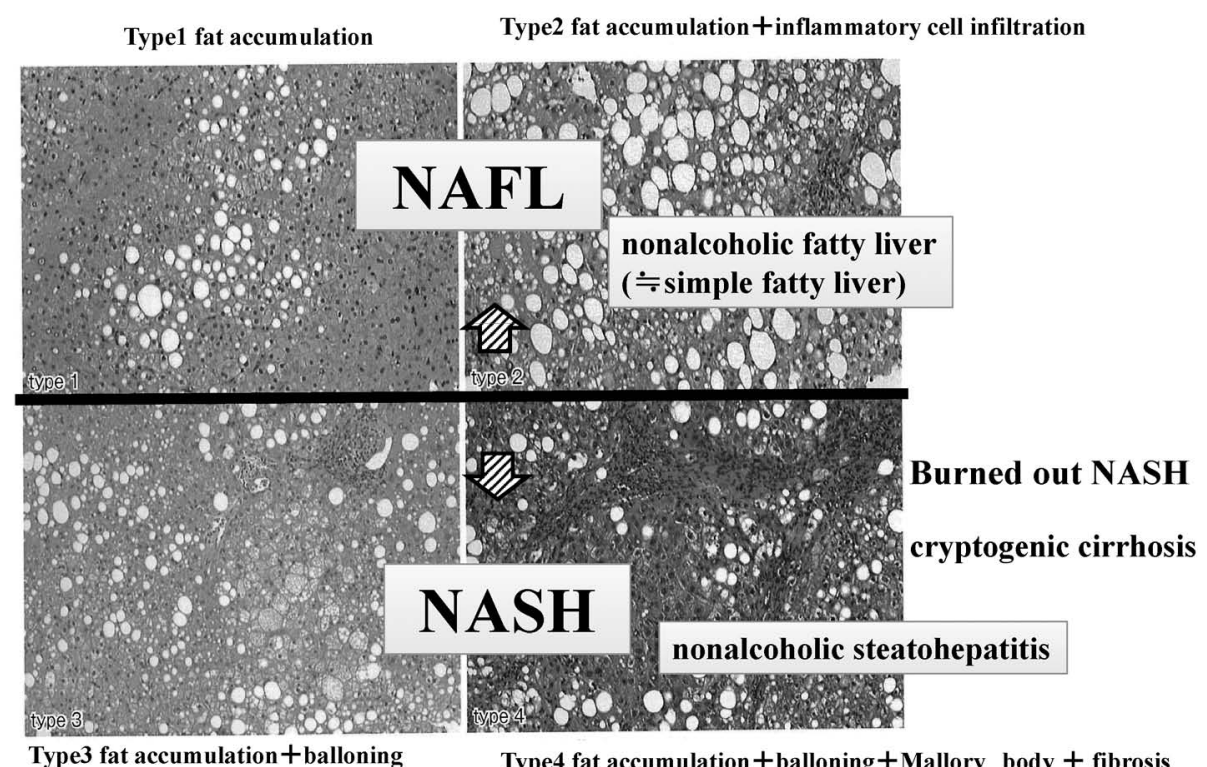

Fig. 5. Histopathological Diagnosis of NAFLD (Matteoni's classfication)

ネクチンの増加, 肝脂肪化の減少, 血清 ALT の低 下，肝星細胞の活性化の抑制作用を示し，臨床的検 討でも RCT で肝脂肪化の改善, 肝炎の抑制効果が 得られた。前述の通り，ビタミン $\mathrm{E}$ ，プラセボと比 較した PIVENS 試験ではビタミン E と比較して有 用性を示せず，肝線化の改善作用も得られなかつ た．ピオグリタゾンはこれまでに最も多く前向き大 規模 RCT による検討をなされており，少なくとも 短期的には NASH に対する有効性が裏付けられて いる. なお，チアゾリジン誘導体は体重増加，心不 全のほかにエビデンスが不十分ながらも骨折, 膀胱 がんのリスクの報告があり, 注意が必要である. ${ }^{2}$

3）スタチン製剤，エゼチミブ

スタチンは HMG-CoA 還元酵素阻害剂であり, 脂質異常症, 特に高コレステロール血症の加療に主 に用いられる。NASH に対するスタチン製剤投与 の検討は概ね良好であるものの，組織学的検討がな されていなかったり他剤が併用されていたりと高い エビデンスレベルの研究にそしい，脂質異常に対す る有効性は明確であることを加味し，高コレステ ロール血症を併発している NASH 患者に対しては 投与を推奨することになった。 エゼチミブは腸管の コレステロールトランスポーターを阻害してコレス テロールの取り込みを抑制することによって, 高コ レステロール血症を改善させる。作用機序からは $\mathrm{NASH} へ$ の有効性が期待され, 小規模の臨床試験
では肝機能, 肝組織の改善効果が報告されている が，エビデンスとしては不十分である. ${ }^{2)}$

4) アンギオテンシン II 受容体拮抗薬

アンギオテンシン II 受容体拮抗薬は高血圧の治療 薬として臨床で使用されているが, 炎症細胞活性化 抑制など他の作用も報告されている。基礎実験では 肝星細胞の活性抑制なども示されており，降圧作用 のみならず他のメカニズムでも NASH 病態進展抑 制効果が期待できる。実際, 小規模の検討では NASH 患者に対して肝機能, 肝組織の改善効果が 得られたという報告がある。しかしながら，十分な エビデンスレベルを有する検討にはそしく, 現時点 では高血圧を有するNASH 患者に対しては降圧剤 として投与し, 副次的に NASH への効果をも期待 する. ${ }^{2)}$

最後にNASH に対して最近日本でも保険適応と なつた肥満手術について述べる.

高度肥満の NASH 患者では手術療法の選択肢に 入る. NAFLD/NASH に対する肥満手術は高度肥 満例の多い米国を中心に行われており，胃バイパス やスリーブ手術が用いられている。 わが国では高度 肥満例に対する腹腔鏡下スリーブ状胃切除術が高度 先進医療として行われていたが，2014 年 4 月から は保険適用となり, 今後施行例が増加すると予想さ れる. 現在の減量手術の適応は肥満による合併症が ある 3 度以上（BMI 35 以上）の肥満患者, 若しく 
は 4 度以上（BMI 40 以上）の高度肥満患者に限定 される. ${ }^{2)}$

\section{7. 予後}

NAFLD の生命予後についての報告は多数ある. 420 例の NAFLD 患者を平均 7.6 年観察した検討で は，年齢，性別をマッチさせた一般住民と比べて， 標準化死亡比 1.34 と有意に高かつた. ${ }^{11)}$ NAFLD129 例を対象とした平均観察期間 13.7 年の 検討からは，NAFL58 例は観察期間中の死亡率 12.1\%であり，一般住民と比べて予後の差はなかつ たが，NASH にまで至っていた 71 例では $26.8 \%$ と，有意に生存率が低かった. ${ }^{12)}$ また，NAFLD173 例を NASH 群 72 例と NAFL 群 101 例に分けた生 命予後の比較検討でも NASH 群のほうが有意に肝 関連死が高かったことが示されている. ${ }^{13)}$ 各研究デ ザインによってデータに幅があるが，NASH の 5 年生存率は 70-95\%, 10 年生存率は 50-90\% であ り，死因として肝臓関連死と心血管死が多いことが 共通した特徵と言える. 他方, 肝発がんについては, NAFLD 6508 人を対象とした検討（観察期間中央 值 5.6 年) では, 16 例 $(0.25 \%)$ が発がんし，年 平均発がん率は $0.043 \%$ であった. ${ }^{14)}$ また，上述の NAFLD420 例の経過を追つた報告では，発がん症 例は観察中（平均観察期間 7.6 年）に 2 例のみ

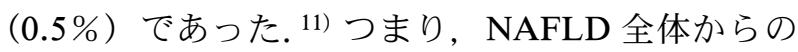
肝発がんの頻度はごくわずかであると言える。一方,

$\mathrm{NASH}$ 症例についてみると, NASH 71 例中，平均 観察期間 13.7 年で肝発がんは 2 例 $(2.8 \%)$ に認め られ，NAFLD 全体よりも高い発がん率を有してい

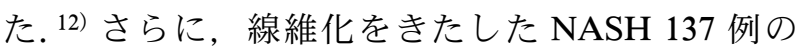
前向きな観察からは，11 例に肝発がんが確認され， 5 年累計発がん率は $7.6 \%$ であったと報告されてい る. ${ }^{15)}$ 同様に，195 例の NASH 肝硬変を対象とした 検討（平均観察期間 3.2 年）では，25 例（12.8\%） に肝がんが発生，年平均発がん率は $2.6 \%$ あ゙あ り,16) 線維化が進展することで発がんリスクが上昇 することが示されている. ${ }^{4}$

8. おわりに

NASH を含むNAFLD は 21 世紀の肝臓病の重要 な一角を占めると予想されるが，診断や治療の確定 にはまだまだ改善の余地が残されており，現在，日 本を含む世界の研究者がしのぎを削つている，薬物 療法の開発のみならず，病因解明においても薬学者
の役割は今後益々大きくなっていることは疑いない.

謝辞 この論文作成にあたつて神戸朝日病院事 務部 宮内美奈子氏に深謝する.

利益相反＼cjkstart開示すべき利益相反はない.

\section{REFERENCES}

1) The Japanese Society of Gastroenterology, "Evidence-based Clinical Practice Guideline for Nonalcoholic Fatty liver Diseases /Nonalcoholic Steatohepatitis 2014," Nankodo Co., Ltd., Tokyo, 2014.

2) Kon K., Watanabe S., Journal of the Japan Pharmaceutical Association, 67, 617-621 (2014).

3) Day C. P., James O. F., Gastroenterology, 114, 842-845 (1998).

4) Romeo S., Kozlitina J., Xing C., Pertsemlidis A., Cox D, Pennacchio L. A., Boerwinkle E., Cohen J. C., Hobbs H. H., Nat. Genet., 40, 1461-1465 (2008).

5) Kawaguchi T., Sumida Y., Umemura A., Matsuo K., Takahashi M., Takamura T., Yasui K., Saibara T., Hashimoto E., Kawanaka M., Watanabe S., Kawata S., Imai Y., Kokubo M., Shima T., Park H., Tanaka H., Tajima K., Yamada R., Matsuda F., Okanoue T., Japan Study Group of Nonalcoholic Fatty Liver Disease, PLoS ONE, 7, e38322 (2012).

6) Kim S. K., Marusawa H., "Kanshikkan Review 2014-2015," Nihon Medical Center, Tokyo, 2014, pp. 80-85.

7) Joka D., Wahl K., Moeller S., Schlue J., Vaske B., Bahr M. J., Manns M. P., SchulzeOsthoff K., Bantel H., Hepatology, 55, 455464 (2012).

8) Hasegawa Y., Kim S. R., Hatae T., Ohta M., Fujinami A., Sugimoto K., Kim K. I., Imoto S., Tohyama M., Kim S. K., Ikura Y., Kudo M., Dig. Dis., 33, 715-720 (2015).

9) Promrat K., Kleiner D. E., Niemeier H. M., Jackvony E., Kearns M., Wands J. R., Fava J. L., Wing P. R., Hepatology, 51, 121-129 (2010).

10) Sanyal A. J., Chalasani N., Kowdley K. V., McCullough A., Diehl A. M., Bass N. M., 
Neuschwander-Tetri B. A., Lavine J. E., Tonascia J., Unalp A., Van Natta M., Clark J., Brunt E. M., Kleiner D. E., Hoofnagle J. H., Robuck P. R., NASH CRN, N. Engl. J. Med., 362, 1675-1685 (2010).

11) Adams L. A., Lymp J. F., St. Sauver J., Sanderson S. O., Lindor K. D., Feldstein A., Angulo P., Gastroenterology, 129, 113-121 (2005).

12) Ekstedt M., Franzén L. E., Mathiesen U. L., Thorelius L., Holmqvist M., Bodemar G., Kechagias S., Hepatology, 44, 865-873 (2006) .

13) Rafiq N., Bai C., Fang Y., Srishord M., McCullough A., Gramlich T., Younossi Z.
M., Clin. Gastroenterol. Hepatol., 7, 234-238 (2009).

14) Kawamura Y., Arase Y., Ikeda K., Seko Y., Imai N., Hosaka T., Kobayashi M., Saitoh S., Sezaki H., Akuta N., Suzuki F., Suzuki Y., Ohmoto Y., Amakawa K., Tsuji H., Kumada H., Am. J. Gastroenterol., 107, 253-261 (2012).

15) Hashimoto E., Yatsuji S., Tobari M., Taniai M., Torii N., Tokushige K., Shiratori K., J. Gastroenterol., 44 (Suppl. 19), 89-95 (2009).

16) Ascha M. S., Hanouneh I. A., Lopez R., Tamimi T. A., Feldstein A. F., Zein N. N., Hepatology, 51, 1972-1978 (2010). 